\title{
Chloroplast DNA variation and phylogeography of Eugenia uniflora L. (Myrtaceae) in the Brazilian Atlantic forest
}

\author{
Andreia Carina Turchetto-Zolet ${ }^{1 *}$, Fabiano Salgueiro ${ }^{2}$, Fernanda Cruz ${ }^{1}$, Nicole Veto ${ }^{3}$, Rogerio Margis ${ }^{1}$ \\ From IUFRO Tree Biotechnology Conference 2011: From Genomes to Integration and Delivery \\ Arraial d'Ajuda, Bahia, Brazil. 26 June - 2 July 2011
}

\section{Introduction and objectives}

The Atlantic Forest (AF) is considered the second largest tropical forest in South America with high species richness and endemisms, harboring a large diversity of animals, plants and habitats types [1]. This biome covers an area of more than one million square kilometres along the Brazilian coast and extending to eastern Paraguay and northeastern Argentina [2]. AF is considered one of the most threatened ecosystems on Earth due to intense disturbance, having been reduced to only $7.5 \%$ of its original area [1]. Despite an increase in research efforts in the past few years, studies of AF species diversification and knowledge about its evolutionary history is still scarce. Vegetation changes in the Atlantic Forest related to climatic changes during the Pleistocene have been registered in paleopalinological studies, with the replacement of large areas of forests by subtropical grasslands and savannas during cooler and drier conditions $[3,4]$. Also, studies of paleoclimatic models, predicted the presence of historically stable areas (refugia) in the Atlantic Forest during the Late Quaternary [5]. Eugenia uniflora L. (Myrtaceae), a shrubby tree with edible cherry-like fruits which is locally known as pitanga or Brazilian cherry. This species is one of the key species in the Atlantic rain forest geomorphological domain, which includes the Atlantic forest and the adjacent Restinga ecosystem [6]. E. unifloraoccurs in areas of medium and large levels of rainfall and can also be found in different vegetation types and ecosystems. This species present economic and folk medicinal applications and is an important pioneer species in the

\footnotetext{
* Correspondence: aturchetto@gmail.com

'Programa de Pós-Graduação em Genética e Biologia Molecular,

Universidade Federal do Rio Grande do Sul (UFRGS), Brazil

Full list of author information is available at the end of the article
}

Restinga ecosystem and has been used to recover and manage disturbed and fragmented areas. Our aim in this study was to investigate the phylogeography and genetic diversity of Eugenia uniflora to help elucidate the evolutionary history of this species as a model for gain insights into past vegetation patterns in the Brazilian Atlantic Forest.

\section{Methods}

Forty-six populations of $E$. uniflora were sampled across the Brazilian Atlantic forest. The samples were collected as leaf material (silica gel dried) from natural populations. Total genomic DNA was isolated using the CTAB method [7]. Two cpDNA regions ( $p s b \mathrm{~A} / \operatorname{trn} \mathrm{H}$ and $\operatorname{trn} \mathrm{C} /$ $y c \mathrm{~F} 6$ ) were using for population analysis based on sequence quality and degree of variation. These regions were amplified using universal primers. The individual consensus sequences were aligned through CLUSTALW [8] implemented in MEGA4 [9], then carefully improved manually. The genealogical relationships among haplotypes were estimated by using the median-joining method implemented in Network 4.2.0.1 (Fluxus Technology Ltd. at http://www.Fluxus-engineering.com). Molecular diversity estimates were calculated using Arlequin 3.1[10] and DNAsp 5.0 [11]. Genetic structure was further examined by the analysis of molecular variance (AMOVA), as implemented in Arlequin version 3.1.

\section{Results and conclusions}

The total combined cpDNA matrix presented 1224 sites, which eight were variable. Eight haplotypes were found and the haplotype diversity $(h)$ ranged from 0 to 0.733 and the nucleotide diversity $(\pi)$ from 0 to 0.00140 . Total haplotype and nucleotide diversities were 0.433 and 0.00088 , respectively. The highest haplotype diversity 
was found in populations ITAP, PALM, CAPI and GRAV from the Atlantic forest South. Populations from Northeast were monomorphic. The most common haplotype was $\mathrm{H} 1$, present in 39 of 46 populations. The AMOVA analysis showed a very strong differentiation among all E. uniflora populations $\left(\mathrm{F}_{\mathrm{ST}}=0.771\right.$, $\mathrm{P}<0.0001)$. These results can help a deeper understanding of the dynamics responsible for both ancient and more recent events that have shaped the current distribution of genetic variability in Atlantic Forest and also have implications for conservation efforts. For the longterm conservation of the genetic diversity of E. uniflora, it would be important to design strategies that aim to preserve most of its lineages. For such, the South region is a key piece, as it houses many divergent and endemic haplotypes and lineages.

\section{Financial support: FAPERGS and CNPq}

\section{Author details}

1Programa de Pós-Graduação em Genética e Biologia Molecular, Universidade Federal do Rio Grande do Sul (UFRGS), Brazil. '2Departamento de Botânica, Universidade Federal do Estado do Rio de Janeiro (UNIRIO), Brazil. ${ }^{3}$ Centro de Biotecnologia, Universidade Federal do Rio Grande do Sul (UFRGS), Brazil

Published: 13 September 2011

\section{References}

1. Myers N: Biodiversity hotspots for conservation priorities. Nature 2000, 403(6772):853-858.

2. Oliveira AT, Fontes MAL: Patterns of floristic differentiation among Atlantic forests in southeastern Brazil and the influence of climate. Biotropica 2000, 32:793-810.

3. Behling $\mathrm{H}$ : South and southeast Brazilian grasslands during Late Quaternary times: a synthesis. Palaeogeogr Palaeod 2002, 177:19-27.

4. Behling H: Late Quaternary environmental changes in the Lagoa da Curuca region (eastern Amazonia, Brazil) and evidence of Podocarpus in the Amazon lowland. Quaternary Res 2001, 56:383-389.

5. Carnaval AC, Moritz C: Historical climate modelling predicts patterns of current biodiversity in the Brazilian Atlantic forest. J. Biogeography 2008, 35:1187-1201.

6. Scarano FR: Structure, function and floristic relationships of plant communities in stressful habitats marginal to the Brazilian Atlantic rainforest. Ann Bot 2002, 90:517-524.

7. Doyle JJ, Doyle JL: Isolation of plant DNA from fresh tissue. Focus 1987, 12:13-15.

8. Thompson JD, Higgins DG, Gibson TJ: Clustal-w - improving the sensitivity of progressive multiple sequence alignment through sequence weighting, position-specific gap penalties and weight matrix choice. Nucleic Acids Res 1994, 22:4673-4680.

9. Tamura K, Dudley J, Nei M, Kumar S: MEGA4: Molecular evolutionary genetics analysis (MEGA) software version 4.0. Mol Biol Evol 2007, 24:1596-1599.

10. Excoffier L, Laval G, Schneider S: Arlequin ver. 3.0: An integrated software package for population genetics data analysis. Evol Bioinformatics Online 2005, 131:479-491.

11. Librado P, Rozas J: DnaSP v5: a software for comprehensive analysis of DNA polymorphism data. Bioinformatics 2009, 25:1451-1452.

\section{doi:10.1186/1753-6561-5-S7-P19}

Cite this article as: Turchetto-Zolet et al:: Chloroplast DNA variation and phylogeography of Eugenia uniflora L. (Myrtaceae) in the Brazilian Atlantic forest. BMC Proceedings 2011 5(Suppl 7):P19.

\section{Submit your next manuscript to BioMed Central and take full advantage of:}

- Convenient online submission

- Thorough peer review

- No space constraints or color figure charges

- Immediate publication on acceptance

- Inclusion in PubMed, CAS, Scopus and Google Scholar

- Research which is freely available for redistribution 